\title{
Dundo, Memória Colonial: A postcolonial return and the documentary politics of history
}

\section{ABSTRACT}

This article presents an analysis of the documentary film Dundo, Memória Colonial ('Dundo, colonial memory') (2009) by the Portuguese journalist Diana Andringa. In the first section, I will inscribe Andringa's film within the wider context of filmic geographies of return. Sections two and three address the multifaceted ways in which colonial Dundo is remembered in Portugal by former settlers and in Angola by former African workers as presented by the film. The fourth section of the article analyses a more personal memory of Dundo that is also developed in this film as the director herself spent her childhood in Dundo. I will conclude that Dundo offers fragmented visions of the past that have to be confronted and discussed in a shared Afro-Portuguese filmic framework. As nostalgic and critical ways of remembering the past are confronted in the film, the documentary proposes that remembering the past is always ambivalent and connected to specific politics of history.

\section{KEYWORDS}

Diana Andringa

Dundo, Memória

Colonial

Diamang

Angolan-Portuguese

Decolonization politics of history documentary film filmic geography of return 


\section{INTRODUCTION}

The film functions like a return to the past, a quest for traces, landscapes, faces. The camera is subjective, or when roaming in the streets or the interior of a house, in search of an image conserved in memories, or distancing itself from me to demonstrate myself alongside those ones whose memories I share.

(Andringa 2011)

The argument of the documentary Dundo, Memória Colonial ('Dundo, colonial memory') (Andringa, 2009) is shaped by the autobiographical memories of Diana Andringa. The journalist was born in Angola in 1947 and today lives in Portugal. She spent her childhood in Dundo, a city in Angola's north-eastern province Lunda, where the Diamond Company of Angola, Diamang, had its administrative headquarters. During colonial rule, Diamang had a quasimonopoly over diamond production in Angola with up to 27,000 workers, while there were only about 200 European settlers working there (Cleveland 2015). One of the settlers was Andringa's father, who worked as an engineer for Diamang. As she recounts in the film's voice-over, Andringa left Angola when she was 11 years old to go to Portugal, where she later studied, became a journalist and came into conflict with the Salazar regime. At first, the film seems to be a very intimate and personal discussion of the past. As Andringa affirms: 'This is a film I was planning to make for a long time, but I was afraid [...] because it was a more personal film [...]; I was not sure if I could find the right way to tell the story' (Andringa cited in Coelho 2009). Andringa also recounts that the years that she spent in Dundo were decisive, both in shaping the idyllic character of a settler childhood and in creating the the sensation of having lived as a child in a world of enormous latent violence' (Andringa cited in Coelho 2009). This statement signals Andringa's critical view of the colonial past, the Portuguese colonial regime in Angola and its repressive character. The production is hence not limited to reflecting on the filmmaker's individual life trajectory. The individual story is rather a point of departure for rethinking the diverging ways of remembering the colonial period in Portugal and in Angola. Consequently, I argue that the film is not merely an autobiographical documentary centred on topics such as displacement, cultural disorientation (Renov 2004: 179) or the question of guilt and shame - with Andringa having being part of a settler society that she later condemned (Macedo and Cabecinhas 2014). Rather, the film can be conceived as a first-person account where the exploration of the filmmaker's own biography is a much less centrally important pursuit [...] than one might expect' (Lebow 2012: 2). Indeed, Dundo contextualizes the filmmaker's individual struggle within the broader socio-political setting, confronting different viewpoints of the colonial past. The film thus carries out its approach in a 'performative mode of critical revisionism' (Huggan 2013: 10). As I will content, the documentary Dundo 'does not seek a corrective to the past so much as to trouble accepted versions of it' (Huggan 2013: 6). The film thereby intervenes in a complex memoryscape haunted by nostalgia, critical engagement and other manifestations that perhaps elude simple categorization. It is an ongoing process where the imperial remains of an empire violently dismembered in the years between 1961 and 1974 are continually negotiated (see e.g. Medeiros 2000; Moutinho 2008; Vieira 2015). On the one hand, postcards and architecture books about the modern and cosmopolitan cities of Luanda 
or Lourenço Marques and memoirs and films contribute towards a nostalgic framing of the past. On the other hand, media productions and books such as Notebook of Colonial Memories by Isabela Figueiredo (2015) offer a radical break with colonialism and raise doubts about the seemingly positive impact that it had on 'whites', 'blacks' or other postcolonial people and landscapes, whether in the Portuguese colonies or in the metropole (Thomaz 2012: 405-07; Kalter 2017). Yet, one can also encounter interventions that do not offer simple solutions, and I argue that Andringa's work is one of them.

In the first section of the article, I will show how the film can be seen as part of a wider context of filmic geographies of return. In section two, I will analyse how Andringa's film produces a dichotomous memory of Diamang and colonial Dundo in Portugal using video testimonies. While former Portuguese settlers and workers of Diamang long for an idyllic life in Dundo, Andringa adopts a critical gaze towards the wrongs of that Angolan settler life. In the third section, I will concentrate on the way in which the film explores recollections of Diamang and the colonial period in Angola. I demonstrate that some of the interviewed people in Angola denounce Portuguese colonialism and Diamang, while others frame the decades before 1974 in a more positive way. Moreover, these viewpoints are not only individual but also articulate arguments connected to broader questions of a 'politics of history' (Onyebuchi Eze 2010), that is, specific ways of seeing the past by political or other actors from civil society to legitimate or criticize certain (hegemonic) positions of power. After having addressed these different politics of history that the film negotiates, a fourth section of the article will be dedicated to the main protagonist's return to Dundo, framing the location as her former hometown. Special attention will be paid to the scenes of the journalist's return to her former homestead to show how the juxtaposition of colonial remains, filmic practices and a subjective voice-over contributes towards the creation of an emergent site of memory, in which different temporal layers are inextricably intertwined. Finally, I will conclude by gesturing towards the ambivalence of remembering the past. As the film's argument suggests, there may be no simple or homogeneous way to shape a collective memory of the colonial past, but rather fragmented visions that have to be confronted and discussed with each other in a common Afro-Portuguese filmic framework.

\section{A FILMIC GEOGRAPHY OF RETURN AND POLITICS OF HISTORY: MEMORIES AND SUBJECTIVITIES}

Dundo, Memória Colonial is one of the films that work on a postcolonial geography of return while addressing questions of memory and articulating specific politics of history. The latter is critically discussed by Onyebuchi Eze, who demonstrates that in the postcolonial era a 'history from above' was used by the new African elites and single parties emerging from the independence struggle to find a way to 'transform [...] the inherited colonial states into an integrated 'Africanized' national territory'. In Eze's view, the 'politicization of history' and the cult of personality developed against a background in the postcolonial era where a 'congruent national memory' was missing: 'history would have to be invented or revisited to conjure an image of national imaginary' (Onyebuchi Eze 2013: 681-82). Melber makes a similar argument for postcolonial states in sub-Saharan Africa, stating that new political regimes 'took a decidedly patriotic form of writing history and turned the independence struggle soon thereafter into a myth' (2009: 451). This official history of 'liberation' is also conveyed by national monuments, their 'monumental 
1. Ball (2018) is an exception as he convincingly shows how the official discourse and its politics of history and monuments are woven together by documentaries and newsreels about colonial Angola. symbolism' and a framework set in the 'paradigm of victory' (2009: 457-58). The conceptual politics of history is hence discussed mainly in the context of political discourses and in terms of official sites of memory. ${ }^{1}$ In my analysis, I take it as a starting point and extend it for a politics of history of the colonial past is currently also produced at a micro level - in relation to dominant master narratives - and even has to be located between Africa and Europe. In addition, I argue that it is important to consider the interplay of filmic visions and ways to think about the past that are situated in the present. Thus politics of history - in the plural - are situated in cinematographically and discursively shaped documentary scenarios that require careful analysis.

Productions such as Andringa's film also need to be seen in the broader context of historical documentaries, in which, according to Nichols, one can observe a shift '[...] from supporting representations of the historical world by experts and authorities to supporting representations that convey more personal, individual perspectives' (2010: 51). This process goes back to the 1960s and the 1970s (Kahana 2016: 531). Within this timespan, objective visions of the past in historical documentaries were not substituted by, but rather complemented with more personalized perspectives on what past social realities and events meant not only to filmmakers but also to (other) people involved in them. From the 1980s onwards, works by John Akomfrah and others began to experimentally tackle questions of identity politics against the backdrop of experiences of migration, racism and colonialism. With respect to the reworking of the colonial past and postcolonial period in the 1990s, it is worth mentioning works by David Achkar, Raoul Peck and Jean-Marie Teno (Aufderheide 2007: 102). These and other filmmakers contributed towards a process in which personal experiences, memories and Eurocentric versions of history were confronted with each other (Thackway 2003: 93). As Aufderheide affirms,

[i]n such works, the private and personal are exposed and sometimes contrasted with the official or public record. Individual memory is juxtaposed with and often challenges public history. New stories surface, and individual experience enriches public understanding of the past.

(2007: 100)

This shift towards more individual perspectives was strongly influenced by the post-1989 changes. In fact, for a long time after 1945, the histories produced in and by documentaries were informed by Cold War politics (Aufderheide 2007: 91). Around 1989, motivated mainly by the radical political and social changes triggered by the fall of the Iron Curtain, the master narratives of the Cold War were losing their credibility. The consequences of this process also unfolded in the socialist regimes in African countries, where discourses about 'national liberation' dominated and protracted civil wars were taking place. A film that famously takes up these issues is Rostov-Luanda (1997) by Abderrahmane Sissako. The documentary critically approaches the recent history of Angola and the Civil War through the lens of the filmmaker's search for an old friend he met in the Soviet Union years before (Armes 2006: 193; McDonogh 2009: 147). Putting aside the dichotomies and political arguments of an anti-capitalist and anti-imperialist discourse, Sissako is able to direct attention towards the stories and social backgrounds of people he randomly encounters while on the road and searching for his lost friend from back then. Drawing on testimony and video interviews about experiences in colonial times and the years 
of the Civil War, the filmmaker's endeavour enables a rather Afro-pessimistic but nonetheless not hopeless view of the developments in Angola.

Using a line of thought similar to that in Sissako's production, Dundo questions the way in which the colonial period is remembered in Portugal and Angola. Andringa's film is thus part of a growing number of documentary and fiction films that raise 'questions about the collective memory of people and nations, about how past events are remembered, as well as what recollections cinematic representations leave aside or choose to ignore' (Faulkner and Liz 2016: 6). It does so by collecting testimonies in both countries. Thereby, it sketches a geography of return in which the filmmaker revisits the sites of her past and colonial history. Consequently, Andringa's production is part of a documentary practice where the return to a specific place of biographical or historical significance is an important move for developing the argument of the film.

The concept of a (filmic) geography of return was developed by Walker (2010). She focuses on post-Katrina video testimony, in which former residents return to their homes to see them destroyed and ruined. Following Walker, the documentaries under consideration constitute an 'affective geography' (2010: 84) of return. Traverso, who draws on her concept in his work about documentaries and nostalgia produced in the post-dictatorship era in Chile, points out that those films allow to 'materialize' on-screen the

intimate yet intangible relationship among several interacting elements: the body of the returning subject who is giving testimony; the place from which this subject's testimony is delivered, which also constitutes the content of the testimony: and the testimony's temporality, which fluctuates between the events as a past whose traces we can interpret from the physical features of the site, and the events' imagined present [...].

By drawing on the concept discussed by Walker and Traverso, I will demonstrate how Andringa's film situates a geography of return between nostalgia and critical engagement through the interrelation of video testimony and sites of memory in Angola and Portugal.

\section{REMEMBERING DUNDO AND DIAMANG IN PORTUGAL}

In this section, I will show how the film Dundo, Memória Colonial makes use of video interviews and a subjective voice-over to present a nostalgic view of the colonial past in postcolonial Portugal. The focus thus lies on how the filmmaker uses her narrator status in the film to demonstrate her dissent with existing ways of remembering the past that highlight the positive aspects of late settler colonialism in Angola.

Consider one of the scenes at the beginning of the film, shot in Portugal, where Andringa is shown looking at family photographs with her daughter and talking about her childhood. While identifying her relatives in the pictures, the journalist quickly goes on to refer to official documents such as her birth certificate and identity card, proving that she was classified as a 'white race' baby and a 'portuguesa de segunda' (00:01:38), a second-class Portuguese citizen. At this early moment in the film, it becomes clear that the production will not only reconstruct a story about Andringa's life as a child in Angola. By pointing to discourses of race and national identity, the scene situates 
Andringa's individual story within the much broader socio-political context of Portuguese colonialism in Angola in the twentieth century. This entanglement of private, historical and political spheres becomes even more obvious as home movie footage of children happily playing in colonial Dundo is shown. Indeed, these idyllic shots of a seemingly fortunate childhood acquire a bitter aftertaste as the voice-over claims that living as a child in Dundo was pleasant and enjoyable - but only for those who were white and children of an engineer working at Diamang.

Similar to the critical view framing the home movies, Andringa also deconstructs colonial newsreel footage showing social activities, leisure time and sports in Dundo during the 1950s and the 1960s. While watching the moving images of swimming pools and tennis courts, in the voice-over the journalist criticizes the colonial regime for its racist rules and segregation practices. She argues that most of the black Africans in Angola were not permitted to take part in such social pleasures, except when working as servants. The film then goes on to explain that there were also sports activities for the African employees at Dundo. However, while doing sports, Angolans remained within a disciplinary framework characterized by the imposition of strict rules, and their achievements were measured by white umpires, the voice-over informs us. While visiting Angola in 1951 at the invitation of the Salazar regime, the Brazilian sociologist Gilberto Freyre observed these racial politics critically. Freyre coined the myth of lusotropicalism, later appropriated as an ideological discourse by the authoritarian regime in Lisbon to legitimize its policy in the so-called 'overseas provinces' (Neto 1997: 330; Castelo 1999; Ball 2018: 79). Consequently, by juxtaposing a subjective voice-over referring to Freyre with the official newsreel footage, a historic reality often hidden by colonial image production (Arenas 2011: 107-08) is problematized and the effect of the propaganda images is disclosed. By drawing both on private and official images and a subjective voice-over, the scene gestures towards a critical discussion of images produced in colonial times and thereby sheds a particularly critical light on the idealized vision suggested by the archival footage on Dundo before 1974.

Having said this, we understand that the beginning of the film aims to outline a critical view of everyday life in colonial Dundo by interconnecting the personal and the political spheres. These scenes serve to evoke Andringa's past as the subject of the film, establishing her as the narrator who will guide viewers throughout the next 60 minutes. Above all, one becomes aware that, although she assumes a subjective viewpoint and is interested in her past, the voice-over is not willing to ignore the historical context of her trajectory. It is important to bear this in mind as the film confronts the journalist's critical memory work with another way of dealing with the colonial past, which is addressed in a sequence of the film beginning at minute ten. There, a group of retornados (returnees) frames their recollections of the time passed in Angola. These returnees were among more than half a million settlers from Angola and Mozambique who arrived in Portugal shortly after the Carnation Revolution on 25 April 1974, when the authoritarian regime of the Estado Novo (New State) was abolished and Angola and other colonies subsequently became independent (Rocha-Trindade 1995; Lubkemann 2005; Kalter 2017). The images of the sequence show an annual meeting of the former Portuguese workers of Diamang that Andringa attended. We see the journalist talking with other participants in a relaxed environment during a lunch party. As the daughter of a renowned engineer, Andringa seems to be cordially received by the other participants. In the course of the scene, we are confronted with 
shots of several former employees explaining their thoughts about Dundo, the childhood, youth or adulthood that they spent in this Angolan town. While the celebratory lunch continues in the background, the interviewed individuals stand in front of the camera, responding to Andringa's questions from behind the camera. Taking into consideration the fact that each person is publicly exposed, it is perhaps unsurprising that positive evaluations predominate their short testimonies. The interviewees present the colonial situation in an idealized manner, and their reflections are limited to autobiographical experiences and contain a vision of the past often articulated by this particular social group (Cleveland 2015: 216). These statements - free from uncertainties or reports of negative, let alone traumatic experiences - do not tackle the contradictions of colonial society or the reasons leading to its abolition. Consequently, the reports tend to reproduce arguments related to the official discourse of the Salazar regime that defended its policy in the African colonies by emphasizing the positive effects of the Portuguese presence in these territories - a view also adopted by films about the Portuguese colonies and Diamang in particular (Ramos 2013; Matos 2016: 190; Ball 2018: 94). In addition, these people do not show much interest in going back to the city that they used to live in until the mid-1970s. Andringa does not judge these explanations directly, although she is highly sceptical of them - for her, these views sometimes seem 'unreal' (00:10:59-00:11:14) as the filmmaker affirms on the voice-over. It seems that the returnees' attitude serves to protect their recollections of an allegedly intact social milieu. The latter seems to be crystallized and furthermore secured by the family photographs that the returnees show around during the meeting images that seem to create a nostalgic view of colonial Dundo. Consequently, the film represents the memories of the former employees of Diamang in a somewhat unified way. There is no place for contradictions or negative experiences here. Their nostalgic memory contrasts with Andringa's approach, enabling the film to suggest an irreconcilable dichotomy between a critical reworking of memory and a simple longing for the past.

\section{RETURN TO ANGOLA: REMEMBERING DIAMANG IN DUNDO}

After exploring the different and seemingly irreconcilable ways of remembering colonial Dundo and Diamang in Portugal, the film turns to Angola. Thus, when the journalist travels to the city of Dundo to further confront her (what she calls naïve) childhood memories, she also interviews a series of Angolans about their feelings, recollections and opinions of the Diamang company and the days of Portuguese colonialism. The first series of recollections of colonial times supports a critical view of colonial Angola as a space of oppressive and violent practices. Here the prevailing arguments focus on a negative evaluation of the Salazar regime, its laws and policies. The interviewees speak about racial segregation in Dundo before 1974; they mention practices of forced labour and corporal punishment and the regular use of the infamous palmatória, a wooden instrument for physical punishment (Penvenne 1995: 108), and they reference the PIDE/DGS, the secret police of the New State, and the torture used against individuals suspected of collaboration with the independence movements in the 1960s and the 1970s (Mateus 2011). Consequently, recollections of Diamang are sometimes mixed with those ones of the colonial period in general. But despite emphasizing negative aspects, these testimonies do not construct their historical witnesses as traumatized. This is not to say that there is no need to acknowledge the violent character of the Portuguese colonial regime in Africa, 
quite the contrary is the case. But bearing in mind the political nature of memories shaped by an ever-changing present and the liberation movements that became political parties and are still in power today, such video interviews could articulate a specific'politics of history' (Onyebuchi Eze 2010: 2013). For instance, one has the impression that some of the testimonies used in Dundo, Memória Colonial that critically highlight the repressive character of colonialism and Diamang seem to be (politically) prefigured by an official discourse about the colonial past. In Angola, this official discourse was mainly coined by the MPLA. According to Melber (2003: xiv-xv), the MPLA can be seen as 'a new political elite' who, by 'employing narratives and memories relating to their liberation wars, has constructed or invented a new set of traditions to establish an exclusive post-colonial legitimacy under the sole authority of one particular agency of social forces'. One way to learn more about the official view of colonialism and Diamang is to turn to a statement by Agostinho Neto from 1977:

Throughout its fifty-six years of existence, Diamang [...] maintaining control of the production and sale of one of the principal riches of the people-diamonds - never once gave the Angolan people the opportunity to participate in the management of this wealth.

(cited in Cleveland 2015: 214)

Although this statement makes no direct reference to the repressive and violent character of the regime, it seems clear that relations between colonizer and colonized are thought of in a dichotomous way, in which repressor and repressed, exploiter and exploited have their respective and unchangeable places. Certainly, such views do inform the way in which the MPLA frames the colonial period. That the MPLA, as the leading political force, has claimed its role of national liberator and combatant against international imperialism by creating a particular politics of history is pointed out by Justin Pearce:

Since 2002, state media and the speeches of MPLA politicians have articulated narratives about anticolonial struggle, the 2002 peace and post-war reconstruction into a coherent discourse about the exclusive legitimacy of the party and, by association with the dos Santos regime, as the embodiment of national identity and the defender of national interest.

(2015a: 116)

Thus, when confronted with statements denouncing either the colonial past or Diamang in the film, one cannot but think of the wider socio-political context of such commentaries. This becomes even more urgent when considering the human rights abuses in the diamond-mining zones as reported by Marques de Morais (2015). The journalist carried out fieldwork in the municipalities of Cuango and Xá-Muteba (Province of Lunda-Norte) in 2009, 2010 and 2011. By interviewing many people in that area, he was able to collect oral testimonies about the social, working and political conditions there. As he states, 'local communities in this region are subject to a regime of corruption, violence, arbitrariness and impunity' (Morais 2015: 5). In his report, Marques shows that diamonds from Angola in fact have to be considered 'blood diamonds': 'local communities in diamond-mining areas are tortured, murdered, and have absolutely no access to justice. Further, they have been systematically and intentionally deprived of developing any means of survival besides diamond digging' (Morais 2015: 5). 
Against this background, it is not surprising that the region around Dundo is still and generally very difficult to access for those seeking to undertake any kind of research (Pearce 2015b). Consequently, it is necessary to question whether the testimonies denouncing Diamang's mistreatment of workers in Andringa's film are haunted not only by arguments informed by an outdated ideological discourse of colonial oppression and the struggle for independence but also by a contemporary socio-economic framework in which state forces and diamond production companies seem to radically disregard citizen rights in that area.

Several of the interviewed persons in the film highlight positive aspects of their life during colonialism: they emphasize that Angolan people could earn a living and they praise the Serviços de Saúde da Diamang (SSD, the company's own health services). One wonders whether this point of view tends to overrate the profit-oriented company's image as one'that cared for the health of its African workers' (Varanda 2010; Varanda and Cleveland 2014: 87-88) because it excludes the SSD's role in providing sufficient healthy and productive, voluntary and forced labour for diamond production at all costs. In the documentary, the interviewees largely echo recent oral histories about Diamang. According to Cleveland, former Angolan employees 'express a genuine nostalgia for the "time of Diamang," a period marked by tranquillity and certainty' (Cleveland 2015: 19). However, it remains unclear whether such statements are also to be understood as a critique of the MPLA's discourse on national history since 1961 (Pearce 2015a: 117). Leaving this question aside, it is important to note that research shows that Africans also remember colonial times positively and nostalgia is hence not exclusively reserved for former settlers (Bissell 2005: 239). In view of these positive recollections, Andringa seeks to understand the reasons behind the idealization of the past among the former 'colonized', which bear an unsettling similarity to those of the former Diamang workers in Portugal. On the voice-over, the filmmaker argues that the experience of the Civil War - in Dundo in the 1990s, where the diamonds were seen as a resource for financing war machinery - has such an impact that the regime before 1974 is perceived as allowing better living conditions than the time after, when Angola became independent. Andringa suggests that the memories of the Civil War obscure negative aspects of Portuguese settler colonialism in Angola. The claim that 'the post-independence chaos that has plagued Lunda undoubtedly heightened these [nostalgic] feelings' (Cleveland 2015: 19) perhaps parallels memory processes in Java (Stoler and Strassler 2000), where people often remember the time of Dutch colonialism in a rather positive way compared to the Japanese occupation during the last years of the Second World War.

To recapitulate this section: In the scenes from Portugal, the film describes a seemingly simple situation regarding the ways of remembering colonial Dundo: from the perspective of the former Portuguese Diamang workers, Dundo was an idyllic place in Africa that provided wealth for them and their families and quite good conditions for the African workers in terms of the extraction work, health issues, children's education and leisuretime activities. One might associate such statements with Ramos' analysis of films such as O Romance de Luachimo - Lunda, Terra de Diamantes (1968), where he emphasizes the significance of such propagandistic films and their impact on 'how we today perceive ourselves and how we perceive the others' (Ramos 2013: 108).

That such a nostalgic view that seems to emphasize or even reproduce the 'Luso-Tropicalist Nation' (Ramos 2013: 108) of Diamang needs to be criticized is highlighted by Andringa and her demand that the past should not be idealized. 
Her claim that the past needs confronting brings the film to contemporary Angola. However, upon arriving in Dundo it becomes evident that Diamang and the colonial regime are not only remembered in a homogeneous way. The film's strength is acknowledging these different and sometimes diverging perspectives. By equally including testimonies denouncing colonial violence and forced labour, and others stressing the advantages of working at Diamang, the documentary complicates the issue of how to frame colonial Dundo in terms of a postcolonial and cinematographically produced remembering that intersects with official discourses and politics of history. Perhaps one might say that the film complicates and provides a further reflection of the different and often opposing views on this colonial site that date back to Freyre's Aventura e Rotina (1953) and his critique of Diamang as an exception from any other 'sweet luso-tropical city' (Bastos 2015: 43) in Angola or elsewhere in the Portuguese colonies.

\section{THE FORMER HOMESTEAD IN DUNDO AS A SITE OF MEMORY}

Besides confronting the different views of Diamang with each other, the film also enacts a personal journey to the country in which Andringa spent her childhood and youth, showing how the filmmaker remembers her early life by returning to several places in Dundo. For instance, one scene shows the local library where the journalist discovered her passion for literature; another one focuses on the (now derelict) swimming pool where Andringa's godmother taught her how to swim. But the most important place that the filmmaker visits is the house where she grew up. In the film, all places mentioned are framed by filmic devices and a subjective voice-over. Consequently, what emerges through the intersection of filmic practices, first-person comment and urban landscape is a cinematographic Dundo, or more precisely, a specific form of a temporally stabilized memory site that is evanescent in character and dependent on transitory ascriptions of the documentary images.

A visit to a former home, as present in Andringa's production, is a current topos in the context of postcolonial geographies of return (Blunt and McEwan 2002) not only in documentary film but also in literary representations. These places are strongly associated with individual experiences and recollections as decisive years of childhood or youth were spent there. Against this background, former homes are connected to processes of identification and emotions of belonging. At the same time, observing them can also motivate reflection on ruptures, fractures, nostalgic viewpoints or even traumatic experiences. Too often, it seems, these places - which no longer exist in their entirety but only as wreckage in the contemporary world - become focal points for those discourses that lament the processes of decline and demise. To be more precise, the ruins of empire are often used as a symbol for a postcolonial failing that happened when - in the case of the former Portuguese territories after 1975 - civil wars, natural disasters and economic crises unsettled young independent states. However, according to Stoler (2008: 196), '[t]o think with ruins of empire is to emphasize less the artefacts of empire as dead matter or remnants of a defunct regime than to attend to their re-appropriations [...] within the politics of the present'. Thus, when turning to the cultural and filmic production of the ruins in Dundo, we have to be attentive to how these colonial remains are functionalized to initiate a specific way of dealing with the past that goes beyond nostalgia or lamenting the actual state of destruction.

As we have already seen, Andringa's documentary Dundo, Memória Colonial develops a rather reflective approach to the topic of memory and postcolonial 
return. When revisiting her former homestead, now a ruined building, a vision of her individual past is proposed through the multi-layered interplay of architectural remains, oral testimony and filmic operations. This effort is simultaneously questioned by foregrounding the fragmentary and ephemeral character of memory itself. While the camera pans over the backyard and the remains of the former homestead, Andringa thus once again uses the voice-over to comment on what the moving images are showing, or rather, what they are not showing:

I show Sofia not the yard that's visible now, but the other one that only I can see, where there's a swing hanging from the mango tree, a cat, and a rabbit called Jack, and my mother's voice chatting to Caquece in the kitchen. And the empty chicken runs where I still see hens, ducks, the other rabbits and the white mice brought from the laboratory. It brings me to the shock of seeing a place I was so happy, in such disrepair. But that happiness was from my childhood, from the people and animals I lived with. After decades of not being able to come here, it's enough to know that what I remember really existed and I can finally share it.

(00:12:28-00:13:14)

One can understand this scene as a reflection about the different situations in which Andringa is walking around Dundo with her daughter Sofia and describing her experiences and memories associated with these places. In a way, this attempt by Andringa to confront her own past and come to terms with it in the present resonates with a description that Apa developed of the homecoming of war refugees: 'A necessary work of inner re-acquaintance, a re-placement of oneself in the network of known objects that can restore the sense of affective roots, and of belonging' (Apa 2010: 251). Furthermore, the scene also aptly demonstrates the transitory character of a filmic staging of memory, which is only temporarily stabilized by drawing on a subjective voice-over and reflexive thinking and colonial remains and filmic practices. All these different aspects contribute towards the inscription of divergent temporal layers in the moving images, in which it becomes possible for past and present to coexist side by side. This, too, is underscored by the use of the pan shot, stressing integrity of space and time and suggesting the possible coexistence of past and present. This filmically produced temporal layering hence contradicts a chronological order in which one actuality is followed by another. In this case, the film rather proposes that different presents - the colonial and the postcolonial - might gain presence simultaneously. Thus the discussion of divergent politics of history advanced by the documentary is complemented by a more personal way of looking at the colonial past.

\section{CONCLUDING REMARKS}

Diana Andringa's Dundo, Memória Colonial opens up a controversial field regarding politics of memory, where different ways of framing the past are confronted with each other, as the film expresses Andringa's aim to 'to disclose the colonial past, the struggles for independence and the memories of those who lived conflict experiences' (Macedo et al. 2013: 164). While the anticolonial stance radically argues for coming to terms with the wrongs and violence committed and acknowledging the victims of the colonial regime, a more nostalgic view denies, or at least does not wish to address, negative 
aspects of the colonial period in Angola. This point of view, which is not restricted to returnees, although often found among them, tends to downplay the repressive character of the colonial regime while emphasizing its achievements. Moreover, one cannot dismiss that Angolans themselves also remember the colonial period in quite different ways: the more or less official position, coined by the MPLA's politics of memory, mainly stresses the points mentioned with respect to the anticolonial stance. Contrary to this, some voices value the colonial period positively.

Besides this schematically sketched panorama of the politics of the past, it is important to point out that these contradicting approaches must also be considered against their contemporary framework. That is, one has to acknowledge the situated character of recollections that are either dependent on biographical trajectories marked by successful socio-economic integration and a rather conservative political point of view (most of the returnees in Portugal) or marked by the circumstances of a protracted civil war and human rights abuses in the diamond-mining zones, such as the Angolan one that is still difficult today, or by political activism (also against the Salazar regime) and civic engagement, as is the case with the filmmaker. In addition, it is crucial to bear in mind that none of the mentioned ways of remembering the colonial past are monolithic entities but may be subject to change, individual interpretation or appropriation, or even read against the grain. Dundo, Memória colonial hence realizes its quest by addressing questions of a shared memory of the colonial past in Europe and Africa. Thus notions such as 'liberation', 'revolution' and 'decolonization' are equally problematized. Their meanings here, like in many other cultural productions, are 'renegotiated in a complex revisionist process that allows the relationship between past and present [...] to be productively reassessed' (Huggan 2013: 4).

Having said this, one might suggest that Dundo continues the discussion of a shared memory as in As duas faces da Guerra (The Two Faces of War) (2007), where the directors Andringa and Flora Gomes question the politics of memory related to the War of Independence in Guinea-Bissau. Such multi-sited approaches were later systematically explored by Joaquim Vieira in the RTP television series A Guerra. Colonial | do Ultramar / de Libertação ("The Colonial / Overseas / Liberation War') (2009-13). A promising recent example that also points in this direction is Independência ('Independence') (2015) by Mário Bastos, a project that addresses the struggle for independence in Angola with testimonies by former and actual members of the MPLA, UNITA and FNLA (Moorman 2017).

Consequently, by constructing a panorama of diverging memories, Andringa avoids trying to solve the problem of how to definitively remember colonial Angola; instead, she explores the ambivalences inherent in processes of perceiving the past:

Ambivalence. The word that haunts me as I walk through Dundo rediscovering the landscape of my childhood. Ambivalence in the words of former employees wishing that the Portuguese return, though not ignoring the perversity of the colonial system. Ambivalence in myself, between the discontent for the Diamang policies and the love for the land that grew under its direction. Between pain for what had disappeared in the meantime and the awareness that its disappearance was inevitable.

(00:35:27-00:35:57, English subtitles in Macedo et al. 2013: 170) 
The filmmaker's comment on the voice-over signals how this cinematographic re-encounter with Dundo motivates her to think about the relationship between past and present. Her words suggest that she is torn between different perspectives, each having its own logic and legitimization. It is a puzzle not easily put together, and the subjectivity constructed by filmic means thus figures as a'site of instability' (Renov 2004: 110). The voice-over's reflection is thereby juxtaposed with a long shot of a drive through the city, recorded in the late afternoon. Filmed from a car, the images frame buildings from the colonial period and some people passing by. This camera movement through the old city area emphasizes the process of dislocation as an art of travelling. By highlighting the experience of being on the road, this scene might also hint at the way in which Andringa's thinking moves back and forth in time. By simultaneously employing images of contemporary Dundo, the film is enriched by temporal layers, giving a present to a past that has (not yet) vanished.

\section{ACKNOWLEDGEMENTS}

A warm thanks to Diana Andringa who provided me with a copy of her film.

\section{REFERENCES}

A Guerra: Colonial / do Ultramar | de Libertação ("The Colonial / Overseas / Liberation War') (2009-13, Portugal: Radio Televisão Portuguesa).

Andringa, Diana (2009), Dundo, Memória colonial ('Dundo, colonial memory') (60 min.), Portugal: LX Filmes.

- (2011), 'Dundo, Memória Colonial', Buala, 3 April, http://www.buala.org/ pt/afroscreen/dundo-memoria-colonial. Accessed 28 April 2018.

Andringa, Diana and Gomes, Flora (2007), As duas faces da Guerra (The Two Faces of War) (100 min.), Portugal: LX Filmes.

Apa, Livia (2010), 'Between fragment and polyphony: Representations of war in Angolan poetry and in Baía dos Tigres and Ilhas de Fogo by Pedro Rosa Mendes', in M. Helena Gonçalves da Silva and Adriana Alves de Paula Martins (eds), Conflict, Memory Transfers and the Reshaping of Europe, Newcastle upon Tyne: Cambridge Scholars, pp. 250-57.

Arenas, Fernando (2011), Lusophone Africa: Beyond Independence, Minneapolis: University of Minnesota Press.

Armes, Roy (2006), African Filmmaking: North and South of the Sahara, Edinburgh: Edinburgh University Press.

Aufderheide, Patricia (2007), Documentary Film: A Very Short Introduction, Oxford: Oxford University Press.

Ball, Jeremy (2018), 'Staging of memory: Monuments, commemoration, and the demarcation of Portuguese space in Colonial Angola', Journal of Southern African Studies, 44:1, pp. 77-96.

Bastos, Cristiana (2015), 'Aventura e rotina: Um livro de meio de percurso revisitado', in Marcos Cardão and Cláudia Castelo (eds), Gilberto Freyre: Novas leituras do outro lado do Atlântico, São Paulo: Editora da Universidade de São Paulo, pp. 35-48.

Bastos, Mário (2015), Independência ('Independence') (110 min.), Angola: Associação Tchiweka de Documentação.

Bissell, William Cunningham (2005), 'Engaging colonial nostalgia', Cultural Anthropology, 20:2, pp. 215-48.

Blunt, Alison and McEwan, Cheryl (2002), Postcolonial Geographies, New York: Continuum. 
Castelo, Cláudia (1999), O modo português de estar no mundo: O luso-tropicalismo e a ideologia colonial portuguesa (1933-1961), Porto: Afrontamento.

Cleveland, Todd (2015), Diamonds in the Rough: Corporate Paternalism and African Professionalism on the Mines of Colonial Angola, 1917-1975, Athens, $\mathrm{OH}$ : Ohio University Press.

Coelho, Alexandra Prado (2009), 'Que país andam os portugueses a filmar', Público, 17 October, https://www.publico.pt/2009/10/17/culturaipsilon/noticia/ que-pais-andam-os-portugueses-a-filmar-243110. Accessed 28 April 2018.

Faulkner, Sally and Liz, Mariana (2016), 'Portuguese film: Colony, postcolony, memory', Journal of Romance Studies, 16:2, pp. 1-11.

Figueiredo, Isabela (2015), Notebook of Colonial Memories (trans. Anna M. Klobucka and Phillip Rothwell), Dartmouth: University of Massachusetts Dartmouth, https://www.umassd.edu/media/umassdartmouth/portgrad/isabelafigueiredo.notebook_colonial_memories_2015.pdf. Accessed 21 January 2018.

Huggan, Graham (2013), 'General introduction', in Graham Huggan (ed.), The Oxford Handbook of Postcolonial Studies, Oxford: Oxford University Press, pp. 1-27.

Kahana, Jonathan (2016), The Documentary Film Reader: History, Theory, Criticism, Oxford: Oxford University Press.

Kalter, Christoph (2017), 'Gente pós-colonial: Quem eram os retornados?', in Elsa Peralta, Bruno Góis and Joana Oliveira (eds), Retornar: Traços de memória do fim do império, Lisbon: Edições 70, pp. 101-20.

Lebow, Alisa (2012), 'Introduction', in Alisa Lebow (ed.), The Cinema of Me: The Self and Subjectivity in First Person Documentary, London: Wallflower Press, pp. 1-12.

Lubkemann, Stephen C. (2005), 'Unsettling the metropole: Race and settler reincorporation in postcolonial Portugal', in Caroline Elkins and Susan Pedersen (eds), Settler Colonialism in the Twentieth Century: Projects, Practices, Legacies, New York, London: Routledge, pp. 257-70.

Macedo, Isabel and Cabecinhas, Rosa (2014), 'Diasporic identity(ies) and the meaning of home in autobiographical documentary films', Lusophone Journal of Cultural Studies, 2:1, pp. 54-71.

Macedo, Isabel, Cabecinhas, Rosa and Abadia, Lilia (2013), 'Audiovisual postcolonial narratives: Dealing with the past in Dundo, Colonial Memory', in Rosa Cabecinhas and Lilia Abadia (eds), Narratives and Social Memory: Theoretical and Methodological Approaches, Braga: University of Minho, pp. 159-74.

Marques de Morais, Rafael (2015), 'Censored book about corruption in Angola now available on RSF site', https://rsf.org/en/news/censored-book-aboutcorruption-angola-now-available-rsf-site. Accessed 19 January 2018.

Mateus, Dalila Cabrita (2011), A PIDE/DGS na Guerra Colonial (1961-1974), Lisbon: Terramar.

Matos, Patrícia Ferraz de (2016), 'Images of Africa? Portuguese films and documentaries related to the former colonies in Africa (first half of the 20th century)', Comunicação e Sociedade, 29:2, pp. 175-96.

McDonogh, Gary W. (2009), Iberian Worlds, New York: Routledge.

Medeiros, Paulo de (2000), 'Hauntings. Memory, fiction and the Portuguese colonial wars', in Timothy G. Ashplant (ed.), The Politics of War Memory and Commemoration, London: Routledge, pp. 201-21.

Melber, Henning (2003), 'Introduction', in Council Human Sciences Research (ed.), Limits to Liberation in Southern Africa: The Unfinished Business of Democratic Consolidation, Cape Town: HSRC Press, pp. xiii-xxiii. 
2009), 'Southern African liberation movements as governments and the limits to liberation', Review of African Political Economy, 36:121, pp. 451-59.

Moorman, Marissa (2017), 'Opening Angola's past to public debate', Africa is a Country, 18 January, http://africasacountry.com/2017/2001/openingangolas-past-to-public-debate/. Accessed 28 April 2018.

Moutinho, Isabel (2008), The Colonial Wars in Contemporary Portuguese Fiction, Woodbridge: Tamesis.

Neto, Maria da Conceição (1997), 'Ideologias, contradições e mistificações da colonização de Angola no século xx', Lusotopie, 4, pp. 327-59.

Nichols, Bill (2010), Introduction to Documentary, Bloomington: Indiana University Press.

Onyebuchi Eze, Michael (2010), The Politics of History in Contemporary Africa, New York: Palgrave Macmillan.

- (2013), 'Pan-Africanism and the politics of history', History Compass, 11:9, pp. 675-86.

Pearce, Justin (2015a), 'Contesting the past in Angolan politics', Journal of Southern African Studies, 41:1, pp. 103-19.

- (2015b), Political Identity and Conflict in Central Angola, 1975-2002, Cambridge: Cambridge University Press.

Penvenne, Jeanne Marie (1995), African Workers and Colonial Racism: Mozambican Strategies and Struggles in Lourenço Marques, 1877-1962, Portsmouth: Heinemann.

Ramos, José da Costa (2013), 'Diamang: Cinema a preto-e-branco', in Maria do Carmo Piçarra and Jorge António (eds), Angola: O Nascimento de uma nação: O Cinema do Império, Lisbon: Guerra e Paz Editores, pp. 97-122.

Renov, Michael (2004), The Subject of Documentary, Minneapolis and London: University of Minnesota Press.

Rocha-Trindade, Maria Beatriz (1995), 'The repatriation of Portuguese from Africa', in Robin Cohen (ed.), The Cambridge Survey of World Migration, Cambridge: Cambridge University Press, pp. 337-41.

Sissako, Abderrahmane (1997), Rostov-Luanda (58 min.), Angola, Mauritania, France, Germany and Belgium: F for Film.

Stoler, Ann Laura (2008), 'Imperial debris: Reflections on ruins and ruination', Cultural Anthropology, 23:2, pp. 191-219.

Stoler, Ann Laura and Strassler, Karen (2000), 'Castings for the colonial: Memory work in "New Order" Java', Comparative Studies in Society and History, 42:1, pp. 4-48.

Thackway, Melissa (2003), Africa Shoots Back: Alternative Perspectives in Sub-Saharan Francophone African Film, Bloomington: Indiana University Press.

Thomaz, Omar Ribeiro (2012), 'Duas meninas brancas', in Elena Brugioni (ed.), Itinerâncias: Percursos e representações da pós-colonialidade, Braga: Húmus, pp. 405-28.

Traverso, Antonio (2013), 'Nostalgia, memory, and politics in Chilean documentaries of return', in Patricia Swier and Julia Riordan-Goncalves (eds), Dictatorships in the Hispanic World: Transatlantic and Transnational Perspectives, Lanham: Fairleigh Dickinson, pp. 49-78.

Varanda, Jorge (2010), 'Crossing colonies and empires: The health services of the diamond company of Angola', in Anne Digby, Waltraud Ernst and Projit B. Mukharji (eds), Crossing Colonial Historiographies: Histories of Colonial and Indigenous Medicines in Transnational Perspective, Newcastle upon Tyne: Cambridge Scholars Publishing, pp. 165-84. 
Varanda, Jorge and Cleveland, Todd (2014), '(Un)healthy relationships: African labourers, profits and health services in Angola's colonial-era diamond mines, 1917-75', Medical History, 58:1, pp. 87-105.

Vieira, Patrícia (2015), 'Imperial remains: Post-colonialism in Portuguese literature and cinema', Portuguese Journal of Social Science, 14:3, pp. 275-86.

Walker, Janet (2010), 'Rights and return. Perils and fantasies of situated testimony after Katrina', in Bhaskar Sarkar and Janet Walker (eds), Documentary Testimonies: Global Archives of Suffering, New York: Routledge, pp. 83-114.

\section{CONTRIBUTOR DETAILS}

Robert Stock is the coordinator of the DFG-research unit 'Participation and Media. Between Demand and Entitlement' at the University of Konstanz. He has a Ph.D. in Cultural Studies and holds a Master Degree in European Ethnography from the Humboldt-University of Berlin. In his dissertation project at the International Graduate Centre for the Study of Culture (Gießen), he analysed postcolonial memory politics in documentary films from Mozambique and Portugal. His main research interests are the mediality of participatory processes, audiovisuality, cultural and media practices of hearing and seeing, representations of disability in media, ambivalences of audiovisual testimony and postcolonial memory politics. Recent publications: (with Mathias Deneke, Anne Ganzert and Isabell Otto) (2016) ReClaiming Participation. Technology - Mediation - Collectivity. Bielefeld: transcript; (2014) 'Archival images and audiovisual testimony: Negotiating the end of empire in the documentary films Guerra Colonial. Histórias de Campanhas em Moçambique (1998) and Natal 71 (1999)' in: International Journal for Iberian Studies 27(2\&3), pp. 183-201; (2012) 'Apologising for colonial violence: The documentary film Regresso a Wiriyamu, transitional justice, and Portuguese-Mozambican decolonisation' in: Reconciliation, Civil Society, and the Politics of Memory: Transnational Initiatives in the 20th and 21st Century, ed. by Birgit Schwelling, Bielefeld: transcript, pp. 239-76.

Contact: Research Unit 'Media and Participation', Department of Literature, Art and Media, Box 157, 78457 Konstanz, Germany.

E-mail: robert.stock@uni-konstanz.de

(iD https://orcid.org/0000-0002-2256-0928 